\title{
PTPN XII: a Company under Monopolistic Competition with Oligopoly Product
}

Both monopolistic competition and oligopoly are represented by imperfect competition condition in the market because it is nearly impossible to find the condition of perfect competition in the real world. The most striking difference between monopolistic competition and oligopoly is the number of firms in the market. There are many firms in monopolistic competition while there are only few in oligopoly. (Ferrer, 2013) Another characteristics in monopolistic competition are: easy or low barriers to entry, products that are resemble but are differentiated, and some pricing power. (Etro, 2017)

PT Perkebunan Nusantara XII, that is abbreviated as PTPN XII is engaged in plantations for cocoa, tea, sugar cane, rubber and coffee. (Pratono \& Radjamin, 2012) First, in terms of the types of products produced, we can see that the products produced are plantation products which actually have product characteristics that are similar to or almost the same as other companies that also produce plantation products. To differentiate their products, PTPN XII does not sell their plantation products directly, but processes them into products that have unique characteristics produced by PTPN XII. PTPN XII not only sells semi-finished plantation products, but also opens a subsidiary called Rollaas Cafe. By opening Rollas Cafe, this shows that there are other differentiation games played by PTPN XII to show that Rollas Cafe is a cafe that sells specialty coffee produced by PTPN XII. We can see that this strategy is a differentiation strategy to differentiate PTPN XII's product from other similar products. So it can be concluded that PTPN XII is under the monopolistic competition.

Secondly, from the point of view of many companies, companies that produce plantation products, especially coffee, can be encountered very much. Within the country alone, in Indonesia, based on data from the Ministry of Industry of the Republic of Indonesia, there are tens or even hundreds of companies related to coffee production. This shows that PTPN XII is not alone or accompanied only by several companies, but there are many companies in this coffee market. Thus it can be concluded that PTPN XII company itself is under monopolistic competition.

Kopi Luwak is one of its 'famous product'. Kopi Luwak is type of coffee that yielded from the best coffee beans which are selected and eaten naturally by the animal named civet or Luwak for its local name. Because of its production process that is labor-intensive, the cost or the price of this product is high. And also, because of it, not so many company could also produce this type of coffee. Because it is hard enough to produce Kopi Luwak and not many companies can do it and immediately succeed, so if there is a company that only produces 1 type of product, namely Kopi 
Luwak, it can be said that company is under the oligopoly market. The condition that the company only produces Kopi Luwak makes it an oligopoly market because there are not many or there will only be a few companies that can focus on producing only 1 unique coffee. Or it can be said that if there will be a market in the future which really focuses only on the specialization of Kopi Luwak production with various developments, then in my analysis the market will be an oligopoly market. But, because PTPN XII is not only focus producing one type of product, then PTPN XII is considered under the monopolistic competition.

\section{Bibliography}

Ferrer, C. E. (2013). Oligopsony-Oligopoly the Perfect Imperfect Competition. Procedia Economics and Finance, 5, 269-278. https://doi.org/10.1016/S2212-5671(13)00033-6

Etro, F. (2017). Microeconomics: Research in economics and monopolistic competition. Research in Economics, 71, 645-649. https://doi.org/10.1016/j.rie.2017.10.009

Pratono, A.H. \& Radjamin, I.P. (2012). Kopy Luwak: a conservation strategy for global market. Emerald Emerging Markets Case Studies, 2(8). https://doi.org/10.1108/20450621211294416 